\section{Deducing the Bio-Perspective Capabilities of Fe(II) Oxidizing Bacterium Isolated from Extreme Environment}

\author{
Somesh Mishra ${ }^{1}$, Rajnish P singh ${ }^{2}$, Smita Raghuvanshi ${ }^{1^{*}}$ and Suresh Gupta ${ }^{1}$ \\ ${ }^{1}$ Department of Chemical Engineering, Birla Institute of Technology and Science (BITS), Pilani, Rajasthan, India \\ ${ }^{2}$ Department of Biological Sciences, Birla Institute of Technology and Science (BITS), Pilani, Rajasthan, India
}

"Corresponding author: Smita Raghuvanshi, Department of Chemical Engineering, Birla Institute of Technology and Science (BITS), Pilani-333031, Rajasthan, India, Tel: +91 9772974341; E-mail: smita@pilani.bits-pilani.ac.in

Rec date: Jan 05, 2015; Acc date: Mar 26, 2015; Pub date: Mar 28, 2015

Copyright: (c) 2015 Mishra S, et al. This is an open-access article distributed under the terms of the Creative Commons Attribution License, which permits unrestricted use, distribution, and reproduction in any medium, provided the original author and source are credited.

\begin{abstract}
Rigorous utilization of chemical fertilizers, monoculture and irrigation with surface saline water is globally deteriorating the quality of surface soil. In present work, the halo and alkalo tolarent bacterium strain isolated from extreme environment, was explored for producing plant growth hormones, that could be used for salt stress up gradation of the crops. The 16S rRNA gene sequencing was used for analysis of salt tolerant bacterium. The bacterium was identified as Pseudomonas aeruginosa KP163922. The Pseudomonas aeruginosa KP 163922 showed plant growth promotion traits, production of industrially important enzymes (amylase, protease and cellulase) and tolerance to more than $4 \% \mathrm{NaCl}$. The antagonistic test reveals that, the growth of pathogenic gram negative bacterium E. coli and Pseudomonas putida was repressed by Pseudomonas aeruginosa KP163922.
\end{abstract}

Keywords: Pseudomonas, Plant growth promoting characteristics; Salinity; Antagonistic test

\section{Introduction}

The organisms that are able to survive in hyper-saline and alkaline condition are halophilic microorganisms. The natural habitat for these microorganisms are hyper-saline lake, soda lake, evaporation pond, saline soil etc. $[1,2]$. Also, the growth of crop and its productivity is affected by the salinity and alkalinity of the soil. Thus, the utilization of haloalkalophilic bacterium for reducing the effect of salinity and alkalinity has drawn considerable attention to promote plant growth. The salinity and alkalinity of the soil is increasing day by day because of the extensive use of chemical fertilizer, monoculture and irrigation with surface saline water. Hence, the halotolerant bacteria adapted to that environment and possessed the ability to produce plant growth hormones, and mineral solubilization may be an option to ameliorate salt stress [3,4]. The potential biotechnological applications and products associated with haloalkalophiles drawn a considerable attention in past decade. With the isolation of new microbial strain the prospects of its utilization increases in numerous ways. The utilization of alkaline proteases in detergent sector, DNA polymerases having application in polymerase chain reaction (PCR). Alkali and thermostable xylanases are useful in pre-bleaching of pulps in order to reduce chlorine requirement in pulp bleaching. Optical switches, medical plastic, oil recovery, antitumor drugs are the few examples of the numerous application of halophiles [5].

The objective of the present study was the isolation and characterization of chemolithotropic iron II oxidizing bacteria in terms of bio-control and plant growth promoting activity. In the present work the chemolithotropic iron II oxidizing bacteria was isolated from Sambhar salt lake, Rajasthan, India. The geographical coordinates of the lake are $26058^{\prime} \mathrm{N}$, and $7505^{\prime} \mathrm{E}$ in the middle of a closed depression in the Aravalli schist, approximately $65 \mathrm{~km}$ northwest of Jaipur, with its axis northwest to southeast (Aggarwal
1951). The total salinity of the lake is $7 \%(w / v)$ with salt concentration in the range of $12 \%$ to $30 \%(\mathrm{w} / \mathrm{v})$. The sulphates, carbonates, bicarbonates, chlorides, sodium and smaller amounts of potassium salts are the major contributor to the salinity. The $\mathrm{pH}$ was in range of 9.5-10. The presence of total suspended solid $07-2.8 \%(\mathrm{w} / \mathrm{v})$ was reported [6]. Thus, the Sambhar salt lake is a natural habitat for the halophilic microorganisms. The isolated strain was acclimatized and enriched in laboratory condition.

\section{Materials and Methods}

\section{Preparation of media}

The media, Minimal Salt Medium (MSM), prepared with the following composition (in g l-1): $\mathrm{NaCl}$ : 29.22, KCl: $0.2, \mathrm{KNO}_{3} 5 \mathrm{mM}$, $\mathrm{NH}_{4} \mathrm{Cl}: 1 \mathrm{mM}, \mathrm{MgCl}_{2} \cdot 6 \mathrm{H}_{2} \mathrm{O}: 0.2, \mathrm{~K}_{2} \mathrm{HPO}_{4}: 0.5, \mathrm{MgSO}_{4} \cdot 7 \mathrm{H}_{2} \mathrm{O}: 0.5$, $\mathrm{KH}_{2} \mathrm{PO}_{4}: 0.2, \mathrm{FeSO}_{4} .7 \mathrm{H}_{2} \mathrm{O}: 14$ in distilled water. Stock MSM solution of $500 \mathrm{ml}$ was taken in $1000 \mathrm{ml}$ Erlenmeyer flask and was autoclaved. The $\mathrm{pH}$ of autoclaved MSM solution was measured and adjusted using $2 \mathrm{M} \mathrm{NaOH}$ solution at $\mathrm{pH} 10$.

\section{Isolation of Iron II oxidizing bacterial species}

The sample from Sambhar lake was brought to the laboratory in autoclaved sample vials of $15 \mathrm{~mL}$ and stored at $20^{\circ} \mathrm{C}$ for further studies. In $1 \mathrm{~L}$ conical flask, $500 \mathrm{~mL}$ of MSM was taken and $2 \mathrm{~mL}$ of the sambhar lake sample was added to it. The flask was incubated at $37^{\circ} \mathrm{C}$ and at speed of $150 \mathrm{rpm}$ for $48 \mathrm{~h}$. After $48 \mathrm{~h}$, the $100 \mu \mathrm{L}$ of the fully grown culture was plated on Luria bertani agar plates with dilution coefficients $2,4,6$ and 8 and left for $72 \mathrm{~h}$ at $37^{\circ} \mathrm{C}$ to grow. The isolation was done by following streak-plate protocol and the streaked plates are left for $48 \mathrm{~h}$ at $37^{\circ} \mathrm{C}$ to grow. The glycerol stocks of the isolated species are made and preserved at $(-) 70^{\circ} \mathrm{C}$ for further studies. Isolated microbial strain was cultured in the test tube containing $10 \mathrm{ml}$ of nutrient broth (peptone $-5 \mathrm{gl}^{-1}$, beef extract $-3 \mathrm{gl}^{-1}$, and $\mathrm{NaCl}-5 \mathrm{gl}^{-1}$ 
in distilled water) for $24 \mathrm{hrs}$. Test tubes were cotton plugged. Plating is done to nullify the presence of any contamination.

\section{Species identification}

The slants of pure species were prepared and sent to Xceleris labs, Ahmadabad India for $16 \mathrm{~S}$ rDNA sequencing method. The resulting sequence was entered into the BLAST nucleotide search program of the National Center for Biotechnology Information to obtain closely related phylogenetic sequences. Pairwise alignment, giving closest match was chosen and phylogeny tree was drawn using the MEGA 4 software.

\section{Characterization of isolated microbial species}

Salt tolerance assay: $10 \mu \mathrm{l}$ aliquot of freshly overnight grown culture was inoculated into MSM media supplemented with sodium ion $\left(\mathrm{Na}^{+}\right)$ concentration $(1-6 \% \mathrm{w} / \mathrm{v})$. After $24-48 \mathrm{hrs}$, the absorbance of the culture was determined at $600 \mathrm{~nm}$. Media without inoculums was used as a blank.

Temperature tolerance assay: Isolated bacterial strain was checked for temperature tolerance by growing at varying range of temperature from $30^{\circ} \mathrm{C}$ to $60^{\circ} \mathrm{C}$ in MSM. Each experiment was done in triplicates and run for 48 hrs.

Biochemical characterization of isolated strain: Isolated bacterial isolate was checked for various biochemical test such as amylase, catalase, oxidase, protease, production of ammonia, Antibiotic sensitivity test etc. following the standard procedures.

Assay for amylase production: The ability of the microorganism to digest the starch was screened by starch hydrolysis test. An inoculum from a fresh culture was streaked on the starch agar plate and incubated at $37^{\circ} \mathrm{C}$ for $24 \mathrm{hrs}$. The incubation plate was flooded with gram's iodine to produce a blue colored starch-iodine complex Presence of clear halogen around the streaked colony was considered as positive for amylase production.

Catalase activity: Isolated strain was freshly streaked on clean glass slide and mixed using a sterile tooth pick. Few drops of $3 \% \mathrm{H}_{2} \mathrm{O}_{2}$ was added to the streaked culture. Appearance of bubbles confirmed the presence of catalase activity.

Assay for protease production: Protease production of the strain was checked following the suitable protocol [7]. Isolated microorganism was spot inoculated on skim milk agar plate and kept for incubation for $24 \mathrm{hrs}$. Appearance of halogen around the colony was considered as positive for protease production.

Oxidase activity: Fresh culture of strain was grown in $4.5 \mathrm{~mL}$ of nutrient broth for overnight. After the optimum growth, $0.2 \mathrm{~mL}$ of $1 \%$ $\alpha$-naphthol and $0.3 \mathrm{~mL}$ of $1 \% p$-aminodimethylaniline oxalate was added. Appearance of purple color was observed after 2 mins, indicating as test organism to delayed oxidase positive [8].

Antibiotic sensitivity test: Selected bacterial strain was tested for its resistance against standard antibiotics as supplied by the manufacturer (Himedia, India). namely gentamicin $(30 \mu \mathrm{g})$, ampicillin $(10 \mu \mathrm{g})$, erythomycin $(10 \mu \mathrm{g})$, kanamycin $(5 \mu \mathrm{g})$, tetracyclin $(10 \mu \mathrm{g})$, streptomycin $(25 \mu \mathrm{g})$, and chloramphenicol $(10 \mu \mathrm{g})$ by the antibiotic sensitivity assay. Briefly, the bacterial culture was swabbed onto NA media plates. The standard antibiotic disc $(6 \mathrm{~mm})$ was placed over the media surface and the plates were incubated at $37^{\circ} \mathrm{C}$ for $24 \mathrm{hrs}$. The experiment was done in triplicate. The results were interpreted on the basis of the diameter of inhibition zone using the zone size interpretative chart supplied by the manufacturer (Himedia, India).

\section{Assay for plant growth promoting activity}

Indole acetic acid (IAA) production assay: The ability of isolated microorganism to produce IAA was done following the method described by Gordon and Weber [9]. Isolated microbial strain was grown in Nutrient broth containing $100 \mu \mathrm{g} \mathrm{mL}^{-1}$ Tryptophan for $72 \mathrm{~h}$ at $30^{\circ} \mathrm{C}$ and kept on shaking at $180 \mathrm{rpm} .1 .5 \mathrm{~mL}$ of stationary phase culture was taken and centrifuged at 12,000 rpm for $2 \mathrm{~min}$. In glass tubes, $1 \mathrm{~mL}$ supernatant of culture was mixed with $4 \mathrm{~mL}$ of Salkowsky's reagent and kept at room temperature for $20 \mathrm{~min}$. Optical density was measures spectrophotometrically at $600 \mathrm{~nm}$. The concentration of IAA in each sample was determined from the standard curve of IAA.

Siderophore production: Siderophore production assay of isolated microbial strain was done qualitatively by chome azurole $S$ agar (CAS) described by Schwyn and Neiland [10]. Spot inoculation of the freshly cultured organism was done on the chome azurole $\mathrm{S}$ agar plates and incubated at $30^{\circ} \mathrm{C}$ for $4-5$ days. Development of yellow-orange halogen around the colony was considered as positive for siderophore production.

Phosphate solubilization assay: Phosphate solubilization ability of isolate was done following the method of Mehta and Nautiyal [11] on National Botanical Research Institute's Phosphate Medium (NBRIP) containing insoluble tricalcium phosphate. Freshly grown culture of bacterial isolate was point-inoculated on media and were kept at $28^{\circ} \mathrm{C}$ for 4 days. Clear zone around the inoculated culture was observed as positive for phosphate solubilization activity. Solubilized phosphate was quantified according to the method of Ames et al. [12] keeping $\mathrm{K}_{2} \mathrm{HPO}_{4}$ as standard.

Production of ammonia: Isolated microorganism was assessed for ammonia production as described by Marques et al. [13]. $10 \mu \mathrm{l}$ of freshly grown culture of bacterial isolate was inoculated into $5 \mathrm{~mL}$ peptone broth and incubated for $48 \mathrm{hrs}$ at $37^{\circ} \mathrm{C}$ in a shaking water bath. After incubation, Nessler's reagent $(0.5 \mathrm{~mL})$ was added to tube. The development of yellow to brown color indicated the production of ammonia.

Hydrogen cyanide ( $\mathrm{HCN}$ ) production: $\mathrm{HCN}$ production was evaluated by streaking the isolate on King's B agar medium amended with glycine (4\%). Whatman No.1 filter paper soaked in picric acid ( $0.05 \%$ solution in $2 \%$ sodium carbonate) was placed in the upper lid of plate. The plate was sealed with parafilm and kept for inverted position at $37^{\circ} \mathrm{C}$ for $48 \mathrm{hrs}$. A change of filter paper color from deep yellow to reddish-brown was considered as an indication for HCN production [14].

\section{Test for antagonism}

Antibacterial activity: Antibacterial activity of the isolated strain was checked by well assay method. For antibacterial assay, pathogenic micro-organism such as E. coli and Pseudomonas putida were freshly inoculated in tryptic soya broth for overnight at $37^{\circ} \mathrm{C}$ with constant shaking at $180 \mathrm{rpm}$. A $100 \mu \mathrm{l}$ of this culture was spread on the tryptic soya agar plate under aseptic condition. After the adsorption, well size of $6 \mathrm{~mm}$ was made by metallic borer and filled with isolated strain $\left(10^{8}\right.$ cfu $\mathrm{mL}^{-1}$ ) and kept for incubation at $37^{\circ} \mathrm{C}$ for $48 \mathrm{~h}$. Inhibition of 
Citation: Mishra S, Singh RP, Raghuvanshi S, Gupta S (2015) Deducing the Bio-Perspective Capabilities of Fe(II) Oxidizing Bacterium Isolated

microbial growth around the well was considered as isolated strain having the antimicrobial activity.

Antifungal activity: The isolate was tested for fungal mycelial inhibition by well diffusion method following the modified protocol of Zongzheng et al. [15]. $20 \mathrm{~mL}$ of melted potato dextrose agar was poured in sterile petriplates and allowed to solidify under laminar flow. After the solidification, $100 \mu \mathrm{l}$ of fungal spore suspension in $0.85 \%$ sterile saline was spread on the solidified plate. Well diameter of $6 \mathrm{~mm}$ was made by metallic borer and filled with overnight grown culture of isolate (cfu) and kept for incubation at $28^{\circ} \mathrm{C}$ for seven days.

\section{Result and Discussion}

\section{Molecular identification and characterization of isolated strain}

The strain was identified based on the $16 \mathrm{~S}$ rDNA gene sequence analysis. As shown in Table 1, 16S rDNA sequence analysis indicated that isolated strain has closest homology with Pseudomonas aeruginosa. Phylogenetic tree constructed using the gene sequence of the isolate and representative bacteria of related taxa is shown in Figure 1 . The $16 \mathrm{~S}$ rDNA gene sequence of the strain was deposited in the Gene bank database under accession no KP163922.

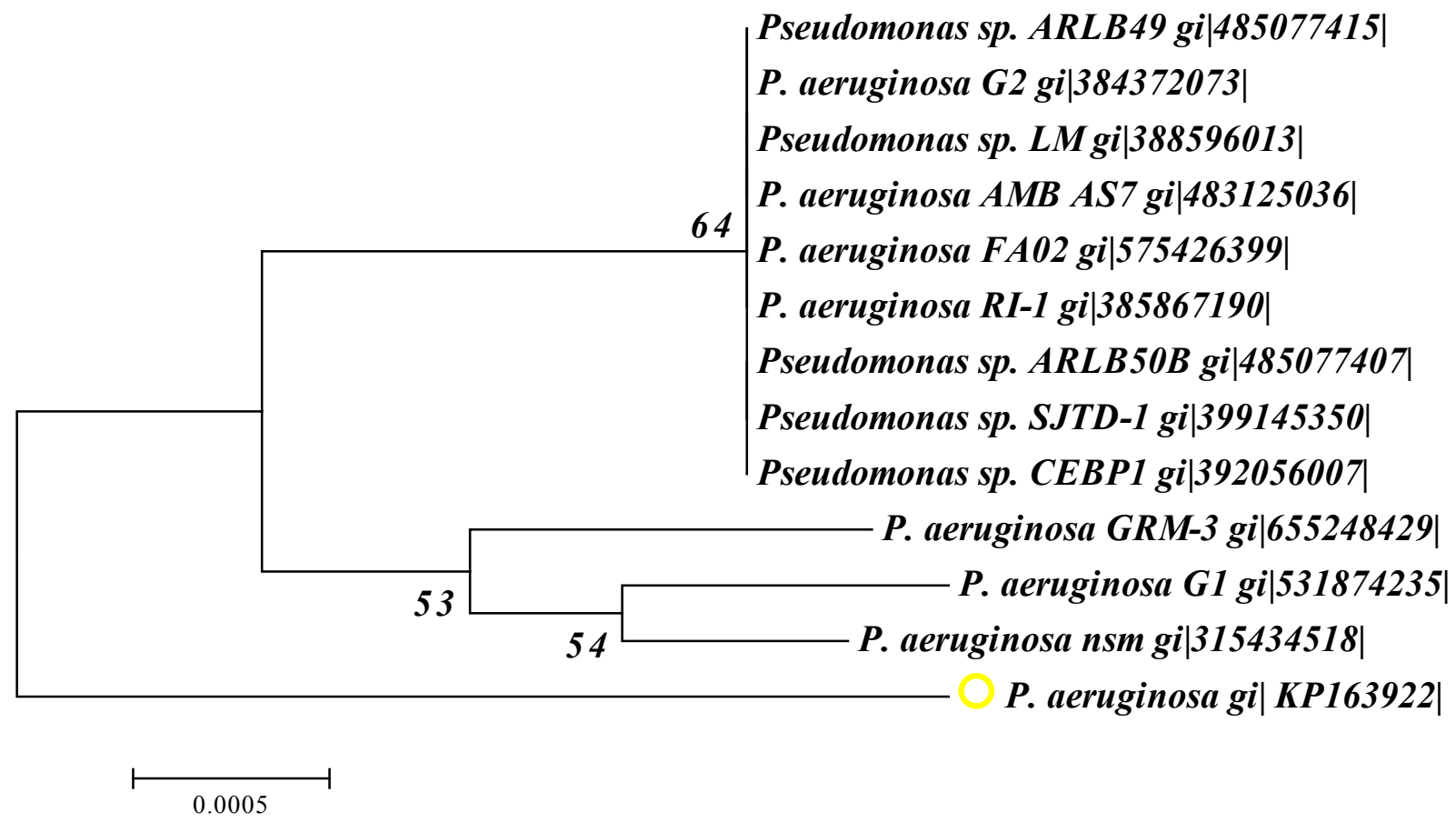

Figure 1: Phylogenetic tree based on 16S rRNA gene sequences showing the relationships between Pseudomonas aeruginosa KP 163922 and its related phylo-genetic neighbors. The topology shown was calculated with the neighbor-joining algorithm. Accession numbers are indicated in brackets. Bootstrap values (\%) are indicated at the branch nodes and were calculated from 500 re-sampled datasets.

Isolated strain gave positive result for the following biochemical characteristics: Catalase production, Amylase and oxidase activity, nitrate reduction. The negative result was observed for urease production (Table 1). Based on the antibiotic resistance profiling, isolate was found to be resistant for Tetracyclin, Chloramphenicol and Vancomycin while sensitive for Gentamycin (Table 1). Isolated strain was able to grow at the maximum salt concentration of $6 \%$ (Table 1) and tolerate the alkalinity up to $\mathrm{pH} 12$ (Table 1).

Plant growth promotion and bio-control activity: The potential PGP mechanisms of the isolate was evaluated in vitro based on the phosphate solubilization in agar plate, ability to produce IAA, siderophore production and HCN production. Production of IAA by the bacterial strains isolated from extreme environments may contribute to the increase in salt tolerance of plants following bacterial inoculation. The phosphate solubilization ability of the bacterial strains regarded as possible mechanism to promote the plant growth. The ferric ion $\left(\mathrm{Fe}^{3+}\right)$ binding capacity in term of siderophore production significantly contribute in enhancing the mobility of insoluble iron-chelate complexes in the soil making it available for microbes and plants. As a consequence of plant growth promotion, the isolate was able to hydrolyze the insoluble mineral phosphate, siderophore production, production of the Indole acetic acid (3.18 \pm 0.16 ), as well as was able to produce HCN (Table 1).

The bio-control ability of the isolate was evaluated based on the in vitro antibacterial and antifungal activity. Isolate was found to inhibit the growth of pathogenic gram negative bacterium $E$. coli and Pseudomonas putida. However no antifungal activity was exhibited by the isolate against the Fusarium graminearum and Fusarium moniliforme (Table 1). 
Citation: Mishra S, Singh RP, Raghuvanshi S, Gupta S (2015) Deducing the Bio-Perspective Capabilities of Fe(II) Oxidizing Bacterium Isolated from Extreme Environment. Biochem Anal Biochem 4: 166. doi:10.4172/2161-1009.1000166

Page 4 of 5

\begin{tabular}{|c|c|c|c|c|}
\hline Isolate & $\begin{array}{l}\text { 16S rRNA gene } \\
\text { identification }\end{array}$ & $\%$ similarity & Gene Bank accession no. & Closely matched organism \\
\hline SSL-4 & Pseudomonas aeruginosa & $100 \%$ & KP163922 & Pseudomonas aeruginosa strain BN5 \\
\hline \multicolumn{5}{|l|}{ Biochemical characteristics of strain } \\
\hline Catalse & \multicolumn{4}{|l|}{+} \\
\hline Amylase & \multicolumn{4}{|l|}{+} \\
\hline $\mathrm{NH}_{3}$ production & \multicolumn{4}{|l|}{+} \\
\hline Nitrate reductase & \multicolumn{4}{|l|}{+} \\
\hline Urease & \multicolumn{4}{|c|}{-} \\
\hline Oxidase & \multicolumn{4}{|l|}{+} \\
\hline \multicolumn{5}{|l|}{ Antibiotic sensitivity test } \\
\hline Tetracyclin & \multicolumn{4}{|l|}{+++} \\
\hline Gentamycin & \multicolumn{4}{|l|}{+} \\
\hline Chloramphenicol & \multicolumn{4}{|l|}{+++} \\
\hline Vancomycin & \multicolumn{4}{|l|}{+++} \\
\hline Tetracyclin & \multicolumn{4}{|l|}{+++} \\
\hline \multicolumn{5}{|l|}{ (: +++ Resistant, + Sensitivity) } \\
\hline $\begin{array}{l}\text { Mineral Phosphate Solubilization } \\
(\mathrm{mM})\end{array}$ & \multicolumn{4}{|l|}{+} \\
\hline $\begin{array}{l}\text { IAA production } \\
(\mu \mathrm{g} / \mathrm{ml})\end{array}$ & \multicolumn{4}{|l|}{$3.18 \pm 0.16$} \\
\hline $\begin{array}{l}\text { Siderophore } \\
\text { production }\end{array}$ & \multicolumn{4}{|l|}{+} \\
\hline HCN production & \multicolumn{4}{|l|}{+} \\
\hline \multicolumn{5}{|l|}{ Antagonistic assay } \\
\hline \multirow[t]{2}{*}{ Antibacterial } & \multicolumn{2}{|l|}{ E. coli } & \multicolumn{2}{|l|}{+} \\
\hline & Pseudomonas putida & + & & \\
\hline \multirow[t]{2}{*}{ Antifungal } & \multicolumn{2}{|l|}{ Fusarium graminearum } & - & \\
\hline & Fusarium moniliforme & - & & \\
\hline
\end{tabular}

Table 1: Strain identification, biochemical characteristics, Antibiotic sensitivity, Plant growth promoting traits and Antagonistic assay of Pseudomonas aeruginosa KP163922.

\section{Conclusions}

P. aeruginosa KP163922 was alkaliphilic and strongly halophilic and found to produce industrially important enzymes viz. amylase, catalase, protease and oxidase. Production of ammonia is an attribute of rhizobacteria which is responsible for plant growth promotion, indirectly by suppressing pathogens and our strain $P$. aeruginosa KP163922 offers considerable promise in agronomic applications, since it shows multiple PGP traits, e.g. Indole acetic acid production, production of $\mathrm{NH}_{3}$, siderophores, phosphate solubilisation, $\mathrm{HCN}$ production and antagonistic activity against bacteria (E. coli, Pseudomonas putida). Thus, the enzymes important for the cycling of carbon, nitrogen, phosphorous and sulphur within the rhizosphere were produced by $P$. aeruginosa SL-72, illustrating its potential as an inoculant to improve plant growth as well as soil fertility.

\section{Acknowledgement}

Authors are thankful to Council of scientific and industrial research (CSIR) and University Grants Commission (UGC), New Delhi, India 
Citation: Mishra S, Singh RP, Raghuvanshi S, Gupta S (2015) Deducing the Bio-Perspective Capabilities of Fe(II) Oxidizing Bacterium Isolated from Extreme Environment. Biochem Anal Biochem 4: 166. doi:10.4172/2161-1009.1000166

Page 5 of 5

for providing facilities to carry out the research work. Authors are thankful to Mr. Maulick Chopra and Mr. Subodh kumar Azad for their constant support and valuable inputs while carrying out the work.

\section{References}

1. Oren A (2002) Diversity of halophilic microorganisms: Environments, phylogeny, physiology, and applications. Journal of Industrial Microbiology \& Biotechnology 28: 56-63.

2. Sorokin DY, Kuenen JG (2005) Chemolithotrophic haloalkaliphiles from soda lakes. FEMS Microbiol Ecol 52: 287-295.

3. Sharma A, Singh P, Kumar S, Kashyap LP, Srivastava KA, et al. (2014) Deciphering Diversity of Salt-Tolerant Bacilli from Saline Soils of Eastern Indo-gangetic Plains of India. Geomicrobiology Journal 32: 170-180

4. Verma S, Prasanna R, Saxena J, Sharma V, Nain L (2012) Deciphering the metabolic capabilities of a lipase producing Pseudomonas aeruginosa SL-72 strain. Folia Microbiol (Praha) 57: 525-531.

5. Horikoshi K (1999) Alkaliphiles: some applications of their products for biotechnology. Microbiol Mol Biol Rev 63: 735-750, table of contents.

6. Joshi A, Seth G (2008) Physico-chemical characteristics of ground water of sambhar lake city and its adjoining area, jaipur district, rajasthan, (India). International Journal of Chemical Science 6: 1793-1799

7. Abo-Aba S, Soliman E, Nivien A (2006) Enhanced production of extra cellular alkaline protease in Bacillus circulance through plasmid transfer. Res Agric Biol Sci 2: 526-530.
8. Kreig, NR, Holf JG (1984) Bergeys Manual of Systematic Bacteriology. William and Wilkins, Baltimore, USA

9. Gordon SA, Weber RP (1951) colorimetric estimation of Indoleacetic acid. Plant Physiol 26: 192-195.

10. Schwyn B, Neilands JB (1987) Universal chemical assay for the detection and determination of siderophores. Anal Biochem 160: 47-56.

11. Mehta S, Nautiyal CS (2001) An efficient method for qualitative screening of phosphate-solubilizing bacteria. Curr Microbiol 43: 51-56.

12. Ames BN (1966) Assay of inorganic phosphate and phosphatases. Method in Enzymology 8: 115-116

13. Marques APGC, Pires C, Moreira H, Rangel AOSS, Castro PML (2010) Assessment of the plant growth promotion abilities of six bacterial isolates using zea mays as indicator plant. Soil Biology and Biochemistry 42: $1229-1235$.

14. Dye DW (1962) The inadequacy of the usual determinative tests for identification of Xanthomonas sp. New Zealand Journal of Science 5: 393-416.

15. Zongzheng $Y$, Xin L, Zhong L, Jinzhao P, Jin Q, Wenyan Y (2009) Effect of Bacillus subtilis SY1 on antifungal activity and plant growth. International Journal of Agricultural and Biological Engineering, 2: $55-56$. 